\title{
ANALISIS KEMAMPUAN PEMAHAMAN KONSEP MATEMATIKA PADA KELAS XI BUDAYA DI SMAK St. FRANSISKUS ASISI LARANTUKA
}

\author{
Agnes Ona Bliti Puka ${ }^{1}$ Marselina Kaha Weking ${ }^{2}$, Philipus Riberto Betan ${ }^{3}$, \\ ${ }^{1,2,3}$ Program Studi Pendidikan Matematika \\ Fakultas Keguruan Dan Ilmu Pendidikan \\ Institut Keguruan Dan Teknologi Larantuka \\ Kabupaten Flores Timur \\ E-mail: agnespucha@gmail.com, marselina weking3@gmail.com
}

\begin{abstract}
Abstrak
Tujuan dari penelitian ini adalah untuk mengetahui kemampuan pemahaman konsep matematika siswa kelas XI Budaya SMAK St. Fransiskus Asisi Larantuka. Data yang dikumpulkan berupa data hasil tes kemampuan siswa dalam memahami konsep matematika dan wawancara tidak terstruktur. Soal tes yang digunakan untuk mengukur kemampuan siswa dalam memahami konsep matematika terdiri dari 2 soal berbentuk uraian dengan materi transpos matriks dan perkalian matriks. Hasil tes kemudian dianalisis berdasarkan indikator pemahaman matematika yaitu: 1) mampu menjelaskan sebuah definisi dengan kata-kata sendiri menurut sifat-sifat/ciri-ciri yang esensial, 2) mampu membuat/meneyebutkan contoh dalam konsep matematika, 3) mampu menggunakan konsep dalam menyelesaikan masalah. Populasi pada penelitian ini adalah seluruh siswa di kelas XI Budaya, SMAK St. Fransiskus Asisi Larantuka dengan mengambil sampel 2 siswa. Hasil dari penelitian ini adalah mengetahui adanya perbedaan kemampuan pemahaman konsep matematika antara siswa melalui model Problem Based Learning (PBL).
\end{abstract}

Kata kunci: Kemampuan pemahaman konsep matematika, transpos matrik dan perkalian matriks.

\begin{abstract}
The purpose of this study is to determine the ability to understand the mathematical concept of students of class XI Culture SMAK St. Francis of Assisi Larantuka. The data collected is in the form of data on students' ability test results in understanding mathematical concepts and unstructured interviews. The test questions used to mesure students' abilities in understanding mathematical concepts consist of 2 questions in the form of descriptions with matrix transpose material and matrix multiplication. The test results are then analysed based on indicators of mathematical understanding, namely: 1) able to explain a definition in their own words according to essential traits/characteristics, 2) able to make/mention examples in mathematical concepts, 3) able to use concepts in solving problems. The population in this study is all students in the class XI Culture SMAK St. Francis of Assisi Larantuka by taking a sample of 2 students. The results of this study are knowing the differences in the ability to understand mathematical concepts between students through Problem Based Learning (PBL).
\end{abstract}

Keywords: Ability to comprehend Mathematical concepts, matrix transpose and matrix multiplication.

\section{PENDAHULUAN}

Pendidikan merupakan salah satu alat untuk meningkatkan taraf hidup bangsa. Pada dasarnya pendidikan merupakan sebuah upaya untuk meningkatkan kualitas sumber daya manusia (SDM). Pendidikan dapat ditempuh, salah satunya di sekolah, dari beberapa mata pelajaran yang di pelajari siswa, matematika merupakan salah satu ilmu yang sangat penting dalam dunia pendidikan. Matematika merupakan salah satu mata pelajaran yang sangat erat kaitannya dengan kehidupan sehari-hari. Pemahaman konsep merupakan bagian yang paling penting dalam pembelajaran matematika. Konsep-konsep pada pembelajaran matematika tersusun secara hierarkis, terstruktur, logis dan sistematis mulai dari konsep yang paling 
sederhana sampai pada konsep yang paling kompleks. Dalam matematika terdapat konsep prasyarat sebagai dasar untuk memahami suatu topik atau konsep selanjutnya. Hal ini sejalan dengan pernyataan Zulkardi (2003) yang menyatakan bahwa mata pelajaran matematika menekankan pada konsep. Ini berarti bahwa ketika siswa mempelajari matematika, memahami konsep matematika harus terlebih dahulu dimiliki siswa untuk dapat menyelesaikan soal-soal serta mampu mengaplikasikan pembelajaran tersebut dalam kehidupan sehari-hari. Berdasarkan penjelasan diatas maka pemahaman konsep perlu ditanamkan kepada siswa sedini mungkin yaitu sejak siswa duduk di sekolah dasar.

Salah satu faktor penting dalam pembelajaran matematika saat ini adalah pentingnya pengembangan kemampuan pemahaman konsep matematika siswa. Tetapi pada kenyataannya sebagian besar siswa mengabaikan pelajaran matematika karena siswa menganggap bahwa matematika itu sulit, membosankan dan tidak menarik. Banyak siswa juga beranggapan bahwa untuk dapat menyelesaikan soal matematika dengan mudah adalah dengan cara menghafal rumus-rumus matematika. Kenyataannya, matematika itu bukanlah pelajaran untuk menghafal rumus, tapi untuk dapat memecahkan masalah matematika, seseorang memerlukan pemahaman yang lebih mendalam. Rumus matematika sangat banyak, tidaklah mungkin jika siswa harus menghafal begitu banyak rumus selama mereka belajar matematika di sekolah.

Kemampuan pemahaman konsep matematika merupakan aspek yang sangat penting dalam pembelajaran, memberi Pengertian bahwa materi-materi yang diajarkan kepada siswa bukan hanya sebagai hafalan, namun lebih dari itu. Dengan pemahaman siswa dapat lebih mengerti akan konsep materi pelajaran itu sendiri. Pemahaman konsep matematika juga merupakan salah satu Tujuan dari setiap materi yang disampaikan oleh guru merupakan pembimbing siswa untuk mencapai konsep yang diharapkan.

Berdasarkan wawancara yang dilakukan, guru mengatakan bahwa kemampuan siswa dalam menyelesaikan soal cerita masih lemah. Salah satu kesulitan yang dialami siswa adalah siswa mengalami kesulitan dalam memodelkan soal cerita ke dalam model matematika. Hal ini disebabkan oleh jarangnya guru memberikan soal cerita yang menyebabkan kurangnya pemahaman terhadap masalah kontekstual. Oleh karena itu pemahaman konsep matematika terhadap masalah merupakan salah satu sasaran yang harus diperhatikan oleh guru dalam proses pembelajaran dikelas. Definisi dari pemahaman konsep (conceptual understanding) menurut Kilpatrick, swatford \& Findell (2001) adalah sebagai kemampuan siswa untuk memahami konsep, operasi dan relasi yang ada dalam matematika. Seseorang yang memiliki pemahaman konsep akan mampu mengkontruksi makna yang diperoleh dari pesan-pesan yang timbul selama proses pembelajaran baik melalui komunikasi lisan maupun tulis. Skemp (1976) menggolongkan pemahaman matematika berdasarkan kemampuan yang dimilikinya, yaitu pemahaman instrumental dan pemahaman relasional. Indikator pemahaman konsep yang digunakan dalam penelitian ini adalah 1) mampu menjelaskan sebuah definisi dengan kata-kata sendiri menurut sifat-sifat/ciri-ciri yang esensial, 2) mampu membuat/meneyebutkan contoh dalam konsep matematika, 3) mampu menggunakan konsep dalam menyelesaikan masalah.

Ada tiga macam pemahaman matematika Menurut Herdian (2010) yaitu pengubahan (translation), pemberian arti (interpretation), dan pembuatan ekstrapolasi (ekstapolation). Pengubahan (translation) memiliki indikator dimana siswa memiliki kemampuan untuk menyampaikan informasi dengan bahasanya sendiri, mampu mengubah kedalam bentuk yang lain yang menyangkut pemberian makna dari suatu informasi yang bervariasi. Jenis pemahaman matematik yang kedua adalah pemberian arti (interpretasi), indikatornya yaitu siswa memiliki kemampuan yang menafsirkan maksud dari bacaan, tidak hanya dengan kata-kata dan frase, tetapi juga mencakup pemahaman suatu informasi dari sebuah ide. Jenis pemahaman matematik yang terakhir adalah pembuatan ekstrapolasi (ekstrapolation), indikatornya yaitu siswa memiliki kemampuan untuk memberikan perkiraan dan prediksi yang didasarkan pada sebuah pemikiran, gambaran kondisi dari suatu informasi, juga mencakup pembuatan kesimpulan dengan konsekuensi yang sesuai dengan informasi jenjang kongnitif ketiga yaitu, penerapan (application). Indikator dari penerapan itu yaitu siswa memiliki kemampuan untuk menggunakan atau menerapkan suatu bahan yang sudah dipelajari kedalam situasi baru, yaitu 
berupa ide, teori atau petunjuk teknis. Sejalan dengan apa yang dikemukakan Herdian sebelumnya, lebih rinci jenjang kongnitif tahap pemahaman itu, Bloom (dalam Suherman \& Sukjaya, 1990:38-45) membaginya menjadi enam, yaitu pemahaman konsep, pehaman prinsip, aturan dan generalisasi, pemahaman terhadap struktur matematika, kemampuan untuk membuat informasi, kemampuan untuk mengikuti pola pikir, kemampuan untuk membaca menginterprestasikan masalah, dan sosial atau data matematika.

Sugandi (Ramadhani 2013:3) mengemukakan bahwa kondisi saat ini dilapangan pada umumnya pembelajaran matematika kurang melibatkan aktifitas siswa.Dan Wahyudin (Rahmadani 2013:3) menegaskan bahwa guru matematika pada umumnya mengajar dengan metode ceramah ekspositosi. Hal ini menunjukan bahwa siswa kurang aktif dalam belajar sehingga kemampuan pemahaman siswa akan pelajaran sangat sulit bahkan banyak siswa yang tidak paham tentang pelajaran yang diberikan dan dijelaskan oleh guru. Penelitian ini dilakukan untuk mengetahui kemampuan pemahaman konsep matematika siswa kelas XI Budaya SMAK St. Fransiskus Asisi Larantuka pada materi Transpos matriks dan Perkalian matriks.

Dalam pembelajaran matematika, guru harus memilih model pembelajaran yang sesuai agar siswa tidak merasa bosan dan lebih menarik perhatian siswa terhadap matematika. Salah satu model pembelajaran yang dianggap sesuai yang dapat meningkatkan pemahaman konsep matematika siswa terhadap masalah adalah Problem Based Learning (PBL).PBL merupakan strategi pembelajaran yang melibatkan siswa dalam memecahkan masalah melalui proses kerja kelompok atau team yang sistematis sehingga siswa lebih aktif dan terampil dalam memberdayakan, mengasah, menguji, dan mengembangkan kemampuan berpikirnya secara berkesinambungan.

Polya (Herdian,2010) membedakan empat jenis pemahaman yaitu: (1) pemahaman mekanikal, yaitu dapat mengingat dan menerapkan sesuatu secara rutin atau perhitungan sedrhana, (2) pemahaman induktif, yaitu dapat mencoba sesuatu dalam kasus sederhana dan tahu bahwa sesuatu itu berlaku dalam kasus serupa, (3) pemahaman rasional, yaitu dapat membuktikan kebenaran sesuatu, (4) pemahaman intuitif, yaitu dapat memperkirakan kebenaran sesuatu tanpa ragu-ragu, sebelum menganalisis secara analitik.

Menurut Tan (dalam Rusman, 2010:229) "pembelajaran berbasis masalah merupakan inovasi dalam pembelajaran, karena dalam PBM kemampuan berpikir siswa betul-betul dioptimalisasikan melalui proses kerja kelompok atau tim yang sistematis, sehingga siswa dapat memberdayakan, mengasah, menguji, dan mengembangkan kemampuan berpikirnya secara berkesinambungan". Sanjaya (2009:214) juga berpendapat bahwa PBL dapat diartikan sebagai rangkaian aktivitas pembelajaran yang menekankan pada proses penyelesaian masalah yang dihadapi secara ilmiah.

Tujuan pembelajaran berbasis masalah dikembangkan untuk membantu siswa mengembangkan kemampuan berfikir, pemecahan masalah, dan keterampilan intelektual Ibrahim (dalam Heriawan, 2012:9). Adapun langkah-langkah pembelajaran PBL yang diungkapkan Woolfook (Nanang,2006:11-12) pada model pembelajaran berbasis masalah terdapat lima tahap yaitu:

1. Orientasi siswa pada masalah, guru menjelaskan tujuan pembelajaran, menjelaskan logistik yang dibutuhkan, memotivasi siswa terlibat pada aktivitas pemecahan masalah yang dipilih.

2. Mengorganisasikan siswa untuk belajar, guru membantu siswa mendefinisikan dan mengorganisasikan tugas belajar yang berhubungan dengan masalah tersebut.

3. Membimbing penyelidikan individual maupun kelompok, guru mendorong siswa untuk mengumpulkan imformasi yang sesuai, melaksanakan eksperimen, untuk mendapatkan penjelasan dan pemecahan masalah.

4. Mengembangkan dan menyajikan hasil karya, guru membantu siswa dalam merencanakan dan menyiapkan karya sesuai seperti laporan, video, dan model dan membantu mereka untuk berbagi tugas dengan temannya.

5. Menganalisis dan mengevaluasi proses pemecahan masalah, guru membantu siswa untuk melakukan refleksi atau evaluasi terhadap penyelidikan mereka dan proses-proses yang mereka gunakan 


\section{METODE}

Jenis penelitian yang digunakan pada penelitian ini adalah deskriptif dengan menggunakan pendekatan kualitatif. Penelitian kualitatif ini merupakan penelitian yang difokuskan untuk mendeskripsikan kemampuan pemecahan masalah siswa menurut langkah Kilpatrick dan Findell pada soal kontekstual yang berkaitan dengan Matriks baik secara individual maupun kelompok, setelah menerapkan pendekatan PBL. Oleh karena itu, jenis penelitian yang sesuai adalah deskriptif kualitatif.

Subjek yang diteliti pada penelitian ini adalah 2 siswa kelas XI Budaya SMAK St. Fransiskus Asisi Larantuka pada tahun ajaran 2020/2021. Pemilihan subjek penelitian berdasarkan kategori jawaban siswa, yaitu: Menyatakan ulang sebuah konsep, Kemampuan mengklarifikasi objek-objek berdasarkan dipenuhi atau tidaknya persyaratan yang membentuk konsep tersebut, Kemampuan menerapkan konsep secara Algoritma, Kemampuan memberikan contoh dari konsep yang dipelajari, Kemampuan menyajikan konsep dalam bentuk representasi matematika, dan Kemampuan mengaitkan berbagai konsep. Peneliti melihat bahwa pemahaman konsep yang dimiliki oleh subjek penelitian masih rendah. Maka dari itu peneliti memutuskan untuk melakukan penelitian di sekolah SMAK St. Fransiskus Asisi Larantuka.

Instrumen yang digunakan oleh peneliti untuk memperoleh, mengolah dan menganalisis data penelitian berupa tes kemampuan pemahaman konsep matematika dan wawancara secara tidak terstruktur untuk menyelesaikan masalah kontekstual yang diberikan oleh peneliti. Instrumen pengumpulan data berupa lembar tes tertulis yang memuat masalah kontekstual yang berkaitan dengan transpos matriks dan perkalian matriks dengan panduan wawancara secara garis besar. Artinya peneliti hanya menyediakan panduan wawancara secara garis besar dan pertanyaan bisa berkembang sesuai dengan jawaban siswa dan informasi yang perlu diperoleh oleh peneliti. Peran peneliti pada penelitian kualitatif adalah sebagai perencana, pengumpul, analisator, penafsiran dan menjadi pelapor dari hasil penelitiannya sendiri. Hal ini sejalan dengan pendapat dari moleong (2013) yang menyatakan bahwa peneliti bertindak sebagai instrument yang utama. Peneliti menyusun sendiri soal yang terdiri dari 2 soal uraian yang berhubungan dengan masalah nyata dengan materi transpos matriks dan perkalian matriks. Teknik analisis data yang digunakan Menurut Herdian (2010), yaitu pengubahan (translation), pemberian arti (interpretation), dan pembuatan ekstrapolasi (ekstrapolation). Hasil pekerjaan dan wawancara siswa akan direduksi dan disajikan dalam bentuk kategori-kategori data berdasarkan langkah pemecahan masalah Kilpatrick dan Findell yaitu, kemampuan menyatakan ulang konsep yang telah dipelajari, kemampuan mengklarifkasi objek-objek berdasarkan dipenuhi atau tidaknya persyaratan yang membentuk konsep tersebut, kemampuan menerapkan konsep secara algoritma, kemampuan memberikan contoh dari konsep yang telah dipelajari, kemampuan menyajikan konsep dalam bentuk representasi matematis, dan kemampuan mengaitkan berbagai konsep. Selanjutnya, data akan dianalisis dan dibahas secara deskriptif kualitatif untuk menjawab rumusan masalah penelitian.

\section{HASIL DAN PEMBAHASAN}

Peneliti melakukan pembelajaran di kelas XI Budaya sebanyak 2 kali pertemuan untuk membelajarkan materi kontekstual yang berkaitan dengan matriks dengan menggunakan pendekatan PBL. Peneliti membentuk 5 kelompok, dimana setiap kelompok terdiri dari 5 siswa yang dipilih secara acak. Di awal pembelajaran peneliti memberikan apresepsi kepada siswa mengenai materi perkalian matriks dan transpos matriks. Selanjutnya peneliti membagikan LKS kepada siswa yang berisi masalah konteks yang berkaitan dengan matriks. Peneliti meminta siswa memisahkan informasi yang terdapat dari masalah tersebut secara teliti. Ketika ada siswa yang mengalami kesulitan dalam pembelajaran, maka peneliti memberikan topangan kepada siswa berupa pertanyaan yang bersifat memancing siswa untuk menemukan jawabannya sendiri. Pada pembelajaran ini, siswa berperan aktif dalam menyelesaikan masalah kontekstual yang diberikan. Selesai mengerjakan soal, peneliti meminta setiap perwakilan kelompok untuk menyampaikan (mempresentasikan) hasil diskusinya di depan kelas, sedangkan kelompok yang 
lain memperhatikan. Jika ada jawaban antar kelompok berbeda, maka peneliti memberikan kesempatan kepada siswa dari kelompok lain untuk menyempurnakan jawaban dari kelompok penyaji. Diakhir pembelajaran, peneliti meminta siswa untuk menyimpulkan pembelajaran, kemudian disempurnakan oleh peneliti.

Berdasarkan pengamatan peneliti terhadap hasil tes kerja siswa dalam bentuk kelompok, bahwa tingkat pemahaman konsep matematika siswa kelas XI Budaya masih sangat kurang. Sehingga pada pertemuan ke 2 peneliti melakukan tes tertulis dan wawancara terhadap siswa kelas XI Budaya SMAK St. Fransiskus Asisi Larantuka untuk meningkatkam kembali pemahaman konsep matematika.

Setelah melakukan pembelajaran pada pertemuan pertama, maka pada pertemuan kedua diadakan tes tertulis dan wawancara tidak terstruktur mengenai soal kontekstual yang berkaitan dengan perkalian matriks dan transpos matriks. Berikut adalah hasil pembahasan mengenai hasil tes dan wawancara siswa (S1 dan S2). Disini karena subjeknya ada 2 siswa, maka peneliti menggunakan sebutan S1 dan S2.

\section{Hasil Pekerjaan \& Wawancara S1}

1. Mampu menjelaskan sebuah definisi dengan kata-kata sendiri menurut sifat-sifat/ciri-ciri yang esensial.

Idikator pertama yang digunakan dalam penelitian ini adalah indikator pemahaman konsep matematika yang mengukur kemampuan siswa dalam menyatakan ulang sebuah konsep dengan bahasanya sendiri, yang berarti kemampuan siswa untuk menyatakan kembali konsep transpos matriks dan perkalian matriks dengan bahasanya sendiri.

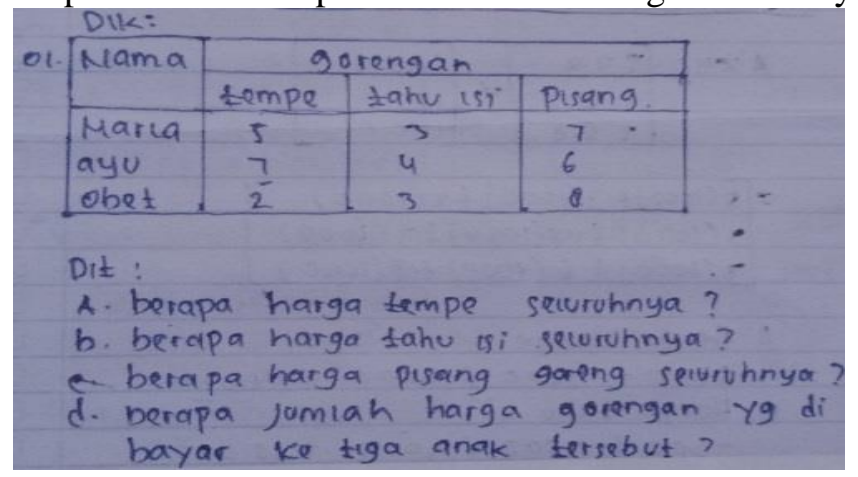

Gambar 1. Jawaban siswa 1

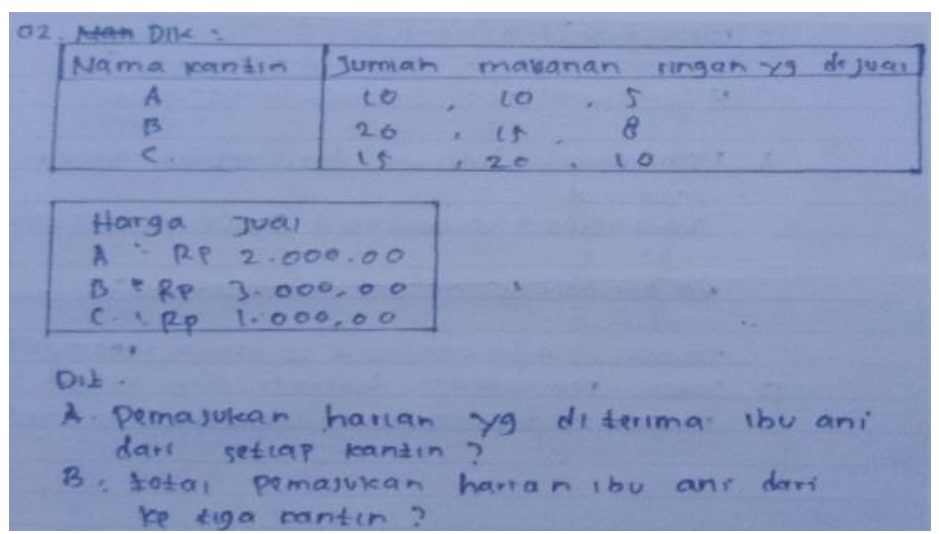

Gambar 2. Jawaban siswa 1

Berdasarkan jawaban siswa 1, sebelumnya menuliskan apa yang diketahui dan ditanyakan pada soal, terlebih dahulu S1 membuat pemisalan menggunakan tabel untuk mengelompokan masalah pada gambar diatas. S1 mampu mendefinisikan kembali transpos matriks dan perkalian matriks. Ini menunjukan bahwa S1 sudah memahami masalah dan menyatakan ulang masalah tersebut menggunakan bahasanya sendiri. 
Berikut adalah kutipan wawancara S1:

$P$ : “Mengapa kamu menggunakan tabel sebagai awal penyelesaian soal?

S1: "untuk mempersingkat atau mempernudah agar saya bisa lebih memahami soal tersebut."

$P$ : "coba kamu jelaskan sedikit berdasarkan pemahaman kamu terhadap soal nomor 1."

S1 : "pada soal nomor 1. Maria, Ayu, dan Obet membeli tempe, tahu isi, dan pisang goreng. Penjual sudah membungkusnya sesuai pesanan ketiganya diplastik yang berbeda, tetapi ketiganya meminta penjual untuk membungkus gorengan disamakan saja sesuai nama gorengannya yaitu tempe satu plastik, tahu isi satu plastik, dan pisang satu plastik."

$P$ : "apa yang ditanya pada soal nomor 1?"

S1: "ada 4 pertanyaan, yaitu: harga tempe seluruhnya, harga tahu seluruhnya, harga pisang goreng seluruhnya, dan jumlah seluruh harga gorengan tersebut".

Berdasarkan kutipan wawancara diatas, dapat dilihat bahwa tingkat pemahaman konsep matematika S1 terhadap masalah dikategorikan baik. Karena S1 mampu menyatakan ulang atau menceritakan kembali masalah tersebut dengan bahasanya sendiri. Tujuan S1 membuat tabel di penyelesaian soal adalah agar mempersingkat dan mempermudah agar S1 bisa menyelesaikan soal.

Berdasarkan hasil pekerjaan siswa dan wawancara S1, dapat disimpulkan bahwa S1 sudah mampu memahami masalah yang diberikan oleh peneliti.

2. Mampu membuat/menyebutkan contoh dalam konsep matematika.

Pengukuran indikator pemahaman konsep matematis S1 tentang mampu membuat /menyebutkan contoh konsep matematika. S1 diminta untuk mengandaikan apabila saat ini S1 menjadi seorang guru, bagaimana S1 memberikan contoh tentang transpos matriks dan perkalian matriks.

Berikut adalah kutipan wawancara S1:

$P$ : “tolong berikan contoh sederhana tentang transpos matriks dan perkalian matriks".

S1: "kalau transpos matriks contohnya misalkan matriks $A=\left[\begin{array}{ccc}5 & 10 & 6 \\ 3 & 2 & 4 \\ 6 & 5 & 10\end{array}\right]$ kemudian di transposkan sesuai dengan konsep transpos matriks menjadi $A^{T}=\left[\begin{array}{ccc}5 & 3 & 6 \\ 10 & 2 & 5 \\ 6 & 4 & 10\end{array}\right]$

$P$ : "kalau contoh perkalian matriks?"

S1: "saya misalkan matriks $A=\left[\begin{array}{lll}2 & 3 & 4 \\ 5 & 6 & 7\end{array}\right]$ dan matriks $B=\left[\begin{array}{c}1000 \\ 2000 \\ 4000\end{array}\right]$ kemudian saya kalikan sesuai dengan lkonsep perkalian matriks yaitu perkalian matriks terjadi ketika banyaknya baris pada matriks pertama yaitu matriks A sama dengan banyaknya kolom pada matriks kedua yaitu matriks $B$."

Berdasarkan hasil wawancara tersebut, $\mathrm{S} 1$ sudah mampu memberikan contoh sederhana yang berkaitan dengan masalah tersebut. Oleh karena itu, dapat disimpulkan S1 memiliki kemampuan memberikan contoh yang berkaitan dengan konsep transpos matriks dan perkalian matriks dengan baik.

3. Mampu menggunakan konsep dalam menyelesaikan masalah.

Mengaplikasikan konsep secara algoritma merupakan indikator ketiga pemahaman konsep matematika yang mengukur kemampuan siswa dalam mengaplikasikan suatu konsep dalam pemecahan masalah berdasarkan langkah-langkah yang benar. 


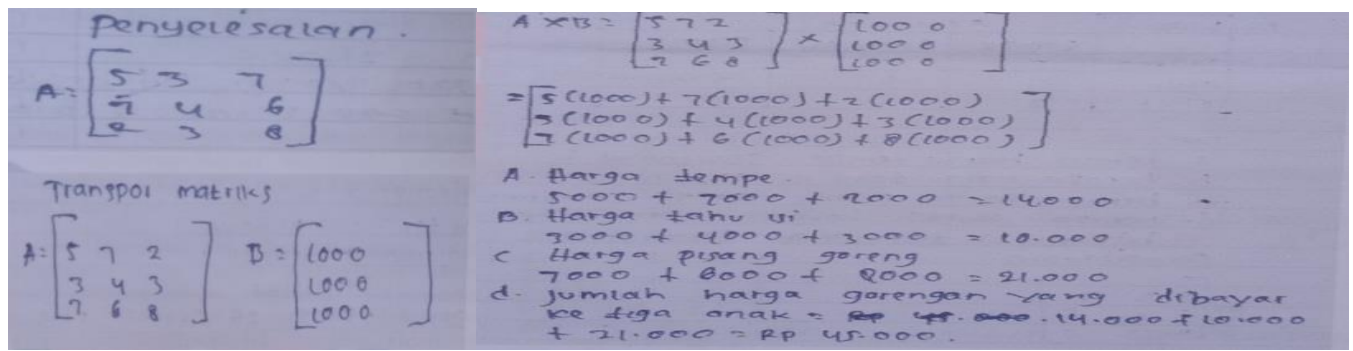

Gambar 3. Jawaban siswa soal nomor 1

Setelah menulis apa yang diketahui dan ditanya pada soal, maka selanjutnya S1 mengubah masalah tersebut ke dalam bentuk matriks. Kemudian S1 melakukan klarifikasi masalah ke dalam bentuk transpos matriks dan perkalian matriks. Dan pada soal nomor 1 juga terlihat bahwa S1 sudah menerapkan konsep transpos matriks dan perkalian matriks secara algoritma. Dengan menjawab soal nomor 1 (gambar 3), S1 mengalikan matriks $A$ (transpos matriks) dengan matriks $B$ (harga) yang sebelumnya sudah dimisalkan untuk menjawab empat pertanyaan pada soal nomor 1 seperti pada gambar 3 diatas.

Berikut adalah kutipan wawancara S1:

$P$ : "apa yang membuat kamu memutuskan bahwa soal nomor 1 diselesaikan menggunakan transpos matriks?"

S1: "karena saya melihat di pernyataan "ketiga anak tersebut meminta penjual membungkus gorengan disamakan sesuai nama gorengan tersebut". Berarti matriks A diubah menjadi matriks AT yang sesuai dengan konsep transpos matriks."

$P$ : "apa konsp dari transpos matriks?"

S1 : "transpos matriks adalah matriks yang elemen-elemennya diperoleh dengan mengubah setiap baris menjadi kolom dan kolom menjadi baris".

Berdasarkan kutipan wawancara tersebut, dapat dilihat bahwa S1 memiliki kemampuan pemahaman yang baik dalam menyelesaikan masalah dengan menerapkan konsep secara algoritma terhadap masalah. S1 juga mengklarifikasi masalah tersebut berdasarkan konsep dari masing-masing masalah dan uraian konsep masalah tersebut. S1 mampu memahami masalah dan mengelompokan masalah tersebut bedasarkan sifat-sifat yang terdapat pada materi transpos matriks.

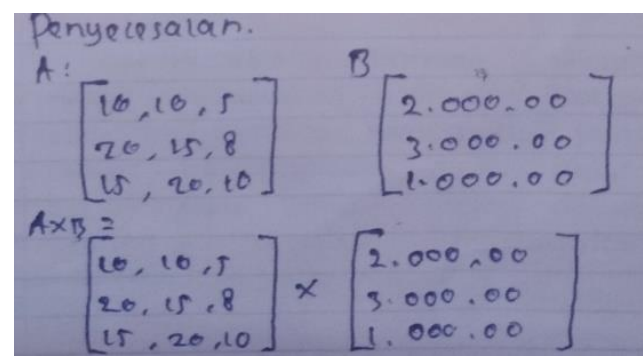

Gambar 4. Jawaban siswa soal nomor 2

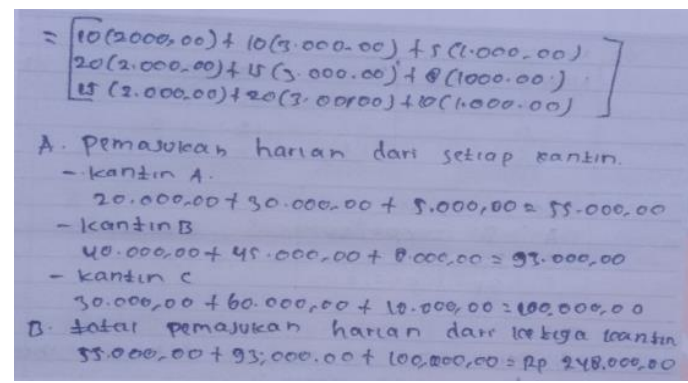

Gambar 5. Jawaban siswa soal nomor 2 
Pada gambar 4 soal nomor 2 ini juga, S1 mengubah masalah tersebut ke dalam bentuk matriks. Kemudian S1 melakukan klarifikasi masalah ke dalam bentuk transpos matriks dan perkalian matriks. Sedangkan, pada soal nomor 2 (gambar 5), S1 mengalikan matriks $A$ (jumlah makanan ringan yang dijual) dengan matriks $B$ (harga jual) sehingga dapat terjawab pertanyaan pada soal nomor 2 .

$P$ : “mengapa kamu menggunakan perkalian matriks untuk menyelesaikan soal nomor 2?"

S1 : "karena pada soal nomor 2 yang ditanyakan adalah pemasukan harian yang diterima ibu Siti dari setiap kantin dan total pemasukan setiap kantin. Sedangkan yang diketahui pada masalah adalah harga dari masing-masing persediaan penjualan ibu Siti.maka dari situ maka maka maka Maka dari itu, saya menggunakan perkalian matriks".

S1 : "apa konsep dari perkalian matriks?"

$P$ : "perkalian matriks terjadi jika ada dua buah matriks dan kedua matriks dapat dikalikan jika banyak baris pada matriks pertama sama dengan kolom pada matriks kedua".

$P$ : “coba kamu jelaskan proses penyelesaian masalah pada soal nomor 2?"

S1 : "pada soal nomor 2 saya langsung kalikan kedua matriks yang saya misalkan matriks $A$ adalah persedian jualan dan matriks B harga jual."

Berdasarkan kutipan wawancara tersebut, dapat dilihat bahwa S1 memiliki kemampuan pemahaman yang baik dalam menyelesaikan masalah dengan menerapkan konsep secara algoritma terhadap masalah. S1 juga mengklarifikasi masalah tersebut berdasarkan konsep dari masing-masing masalah dan uraian konsep masalah tersebut. S1 mampu memahami masalah dan mengelompokan masalah tersebut bedasarkan sifat-sifat yang terdapat pada materi transpos matriks.

Jadi, dapat disimpulkan S1 memiliki kemampuan pemahaman yang baik dalam menerapkan konsep secara algoritma. Dan S1 juga sudah mampu mengkrarifikasi objekobjek berdasarkan dipenuhi atau tidaknya persyaratan yang membentuk konsep tersebut.

\section{Hasil pekerjaan \& Wawancar S2:}

1. Mampu menjelaskan sebuah definisi dengan kata-kata sendiri menurut sifat-sifat/ciri-ciri yang esensial.

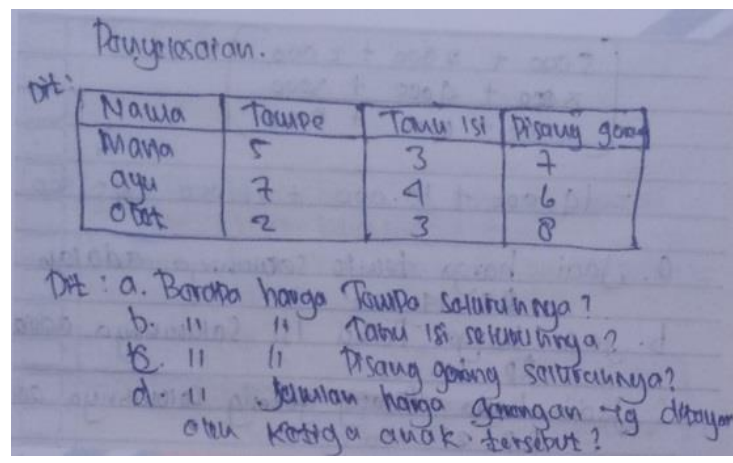

Gambar 6. Jawaban siswa

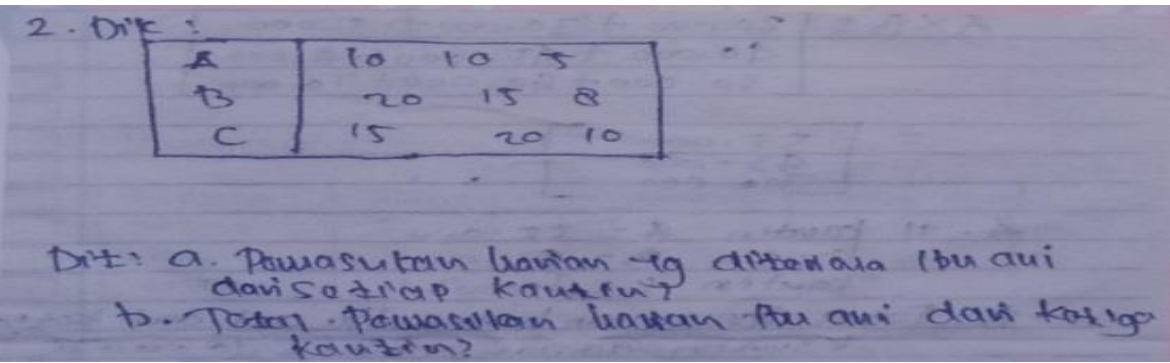

Gambar 7. Jawaban siswa 
Berdasarkan gambar 6 dan gamabr 7, sebelum menuliskan apa yang diketahui dan ditanyakan pada soal, terlebih dahulu S2 membuat pemisalan menggunakan tabel untuk mengelompokan masalah pada gambar diatas. Ini menunjuhkan bahwa S2 sudah memahami masalah dan menyatakn ulang masalah tersebut menggunakan bahasanya sendiri.

Berikut adalah kutipan wawancara S2:

P: "mengapa kamu menggunakan tabel sebagai awal penyelesaian soal?"

S2: "untuk mempermudah menyelesaikan masalah".

$P$ : "coba kamu jelaskan sedikit berdasarkan pemahaman kamu terhadap soal nomor 1"

S2: "untuk soal nomor 1. Maria, Ayu dan Obet membeli jenis gorengan yang berbeda-beda. Jenis gorengan itu diantaranya adalah tempe, tahu isi, dan pisang goreng. Mereka meminta penjual tersebut membungkus pesanan ketiganya disamakan sesuai nama gorengan dan mereka bertiga sepakat untuk mebayar gorengan sesuai dengan isi plastic yang sudah disamakan gorengannya."

$P$ : "apa yang ditanya pada soal nomor 1?"

S2: "harga tempe seluruhnya, harga tahu seluruhnya, harga pisang goreng seluruhnya dan harga gorengan yang harus dibayar ketiga anak tersebut".

Berdasarkan kutipan wawancara diatas dapat dilihat bahwa tingkat pemahaman matematis S2 terhadap masalah dikategorikan baik. Karena S2 mampu menyatakan ulang atau menceritakan kembali masalah tersebut dengan bahasanya sendiri. Tujuan S2 membuat tabel dipenyelesaian soal adalah untuk mempermudah menyelesaikan masalah.

Berdasarkan hasil pekerjaan (gambar 6) dan (gambar 7) wawancara S2, dapat disimpulkan bahwa S2 sudah mampu memahami masalah yang diberikan oleh peneliti.

2. Mampu membuat/menyebutkan contoh dalam konsep matematika.

Berikut adalah kutipan wawancara S2:

$P$ : "coba berikan contoh sederhana tentang transpos matriks!"

S2: "pada suatu hari kory, Karin, dan anggi pergi ke tokoh untuk membeli buku tulis, puplen, dan mistar. Kory membeli 6 buku tulis, 4 pulpen, dan 3 mistar. Karin membeli 8 buku tulis, 5 pulpen, dan 4 mistar. Anggi membeli 5 buku tulis, 3 pulpen, dan 2 mistar. Kemudian ketiga anak tersebut meminta penjual satukan barang sesuai jenis barang yang dibeli".

$P$ : "kalau contoh untuk perkalian matriks?"

S2: "trifon membuka warung usaha, diwarung tersebut dijual berbagai jenis makanan salah satunya adalah es, nasi bungkus, dan kerupuk mempunyai harga berbeda-beda.Es 2000, nasi bungkus 5000, dan kerupuk 3000. Setiap hari trifon menjual hasil bungkus 20, 10, 30, pada warung A. Pada warung B 10, 5, 20.Pada warung C 5, 20, 10.Buatlah kedalam bentuk perkalian matriks ."

3. Mampu menggunakan konsep dalam menyelesaikan masalah.

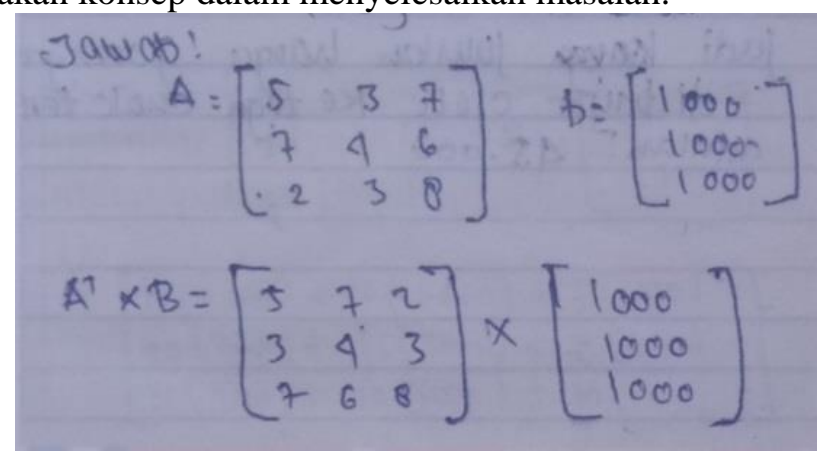

Gambar 8. S2 menyelesaikan soal nomor 1 


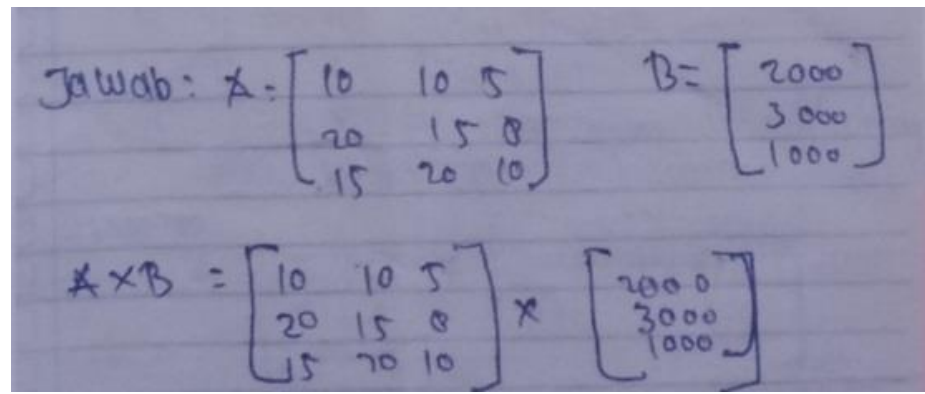

Gambar 9. S2 menyelesaikan soal nomor 2

Setelah menuliskan apa yang diketahui dan ditanya pada soal, maka selanjutnya S2 mengubah masalah tersebut kedalam bentuk matriks. Kemudian S2 melakukan klarifikasi masalah kedalam bentuk transpos matriks dan perkalian matriks seperti gambar 8 dan 9 .

Berikut adalah kutipan wawancara S2:

P: "apa konsep dari transpos matriks dan perkalian matriks dan perkalian matriks?"

S2: "konsep dari transpos matriks adalah pertukaran baris dan kolom sedangkan perkalian matriks adalah mengalikan elemen-elemen baris pada matriks pertama dengan elemen kolom pada matriks kedua."

$P$ : "coba kamu jelaskan syarat perkalian matriks menurut pemahamanmu?"

S2: "menurut saya syarat perkalian matriks adalah matiks pertama harus memilih jumlah kolom yang sama dengan jumlah baris pada matriks ke dua."

Berdasarkan kutipan wawancara tersebut, terlihat bahwa S2 mengklarifikasi masalah tersebut berdasarkan konsep dari masing-masing masalah. Dan uraian konsep masalah tersebut, S2 mampu memahami masalah dan mengelompokkan masalah tersebut berdasarkan sifat-sifat yang terdapat pada materi transpos matriks dan perkalian matriks.

Oleh karena itu.berdasarkan hasil wawancara dan hasil pekerjaan siswa dapat disimpulkan bahwa S2 sudah mampu mengkalrifikasi objek-objek berdasarkan dipenuhi atau tidaknya persyaratan yang membentuk konsep tersebut.

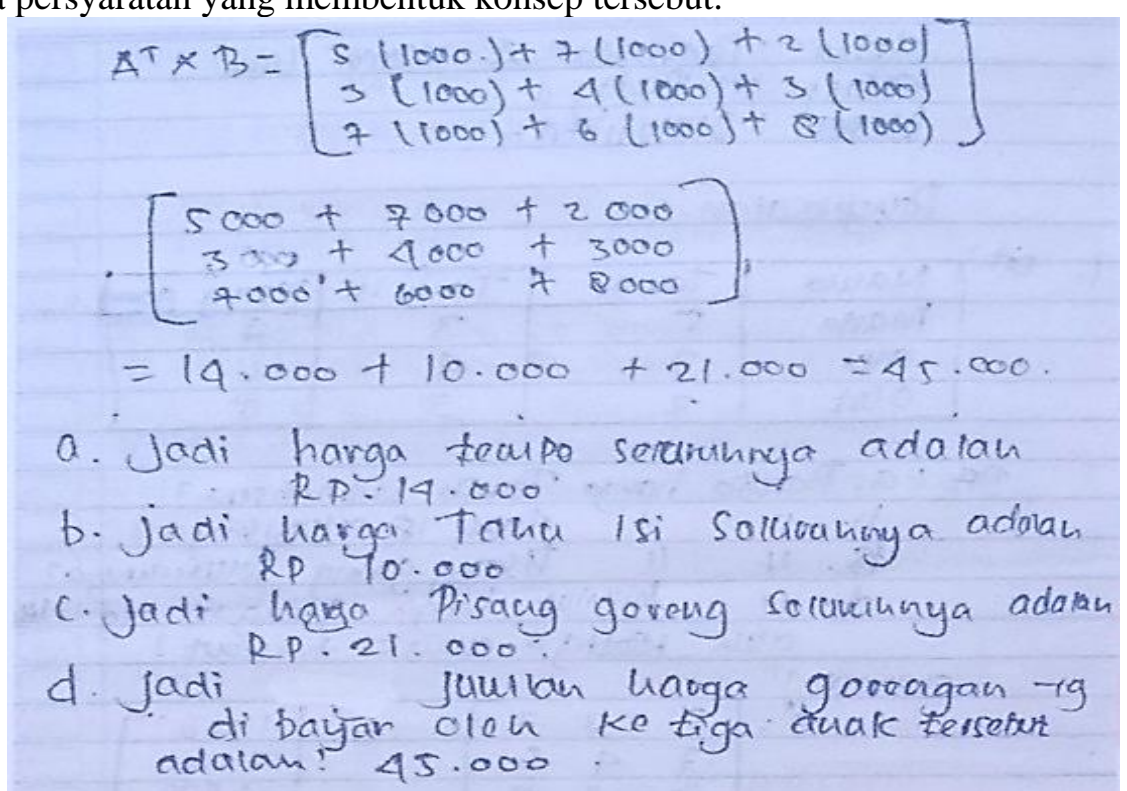

Gambar 10. S2 menyelesaikan untuk mendapatkan jawaban pada soal nomor 1 


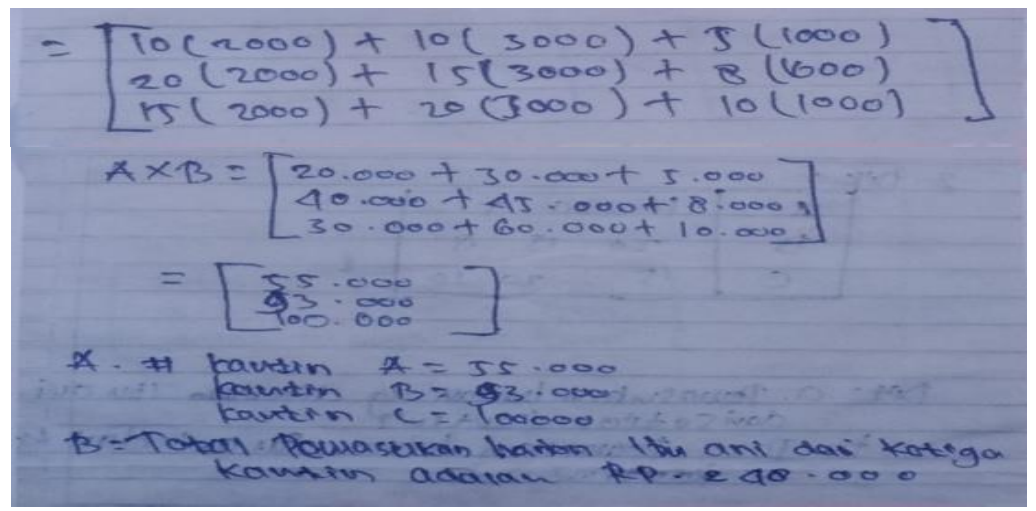

Gambar 11. S2 Menyelesaikan untuk mendapatkan jawaban pada soal nomor 2

Berdasarkan hasil pekerjaan siswa, terlihat bahwa S2 sudah menerapkan konsep transpos matriks dan perkalian matriks secara algoritma. Dengan menjawab soal nomor satu (gambar 11), S2 menulis jumlah tempe, tahu isi, dan pisang goreng kedalam bentuk matriks $A$ dan harga pada matriks $B$. kemudian $\mathrm{S} 2$ mentranspos matriks $A$ menjadi $A^{T}$ dan S2 mengalikan $A^{T} \times B$ seperti terlihat pada gambar.Sedangkan soal pada nomor 2 (gambar 12), S2 langsung mengalikan matriks $A$ (jumlah gorengan) dengan matrik $B$ (harga gorengan).

Berikut adalah kutipan wawancara S2:

P: "coba kamu jelaskan proses penyelesaian masalah pada soal nomor 1."

S2: "yang pertama saya mengalika matriks $A^{T}$ dengan matriks $B$ yang mana matriks $A^{T}$ adalah jumlah jenis gorengan dan matriks $B$ adalah harga gorengan."

$P$ : "bagaimana soal nomor 2?"

S2: "yang saya lakukan adalah mengalikan matriks A dengan matriks $B$ yang mana setiap elemen pada baris pertama matriks $A$ dikalikan dengan elemen pertama pada matrik $B$, kemudian hasilnya dijumlahkan. Selanjutnya elemen baris pada matriks A dikalikan dengan elemen kolom ke dua pada matriks $B$, kemudian hasilnya dijumlahkan."

Berdasarkan kutipan wawancara tersebut, dapat dilihat bahwa S2 memiliki kemampuan pemahaman yang baik dalam menyelesaikan masalah dengan menerapakan konsep secara algoritma terhadap masalah.

Jadi, dapat disimpulkan S2 memiliki kemampuan pemahaman yang baik dalam menerapkan konsep secara algoritma.

\section{SIMPULAN DAN SARAN}

Berdasarkan dari hasil analisis data dan pembahasan, maka dapat disimpulkan bahwa kemampuan pemahaman konsep matematika siswa kelas XI Budaya SMAK St. Fransiskus Asisi Larantuka sebagai berikut: Kemampuan pemahaman konsep matematika dalam menyelesaikan soal kontekstual yang berkaitan dengan transpos matriks dan perkalian matriks setelah diterapkannya model pembelajaran PBL berdasarkan Kilpatrick dan Findell S1 dan S2 memiliki kemampuan pemahaman dalam mengubah masalah kedalam tabel dan memodelkannya dalam bentuk matriks serta diselesaikan dengan ditransposkan dan dikalikan; Kemampuan pemahaman matematis siswa terhadap pemberian contoh dari konsep dan mengaitkan berbagai konsep berbeda S1 memberikan contoh sederhana berupa matriks kemudian diselesaikan dengan ditransposkan dan dikalikan tetapi S2 memberikan contoh berupa soal cerita berupa soal cerita tanpa diselesaikan. Sedangkan pada langkah mengaitkan konsep S1 menjelaskannya pada soal nomor 1 transpos matriks ada kaitannya dengan perkalian matriks. Karena diselesaikan dengan ditransposkan kemudian dikalikan untuk menjawab masalah kontekstual tersebut. S2 mengaitkan konsep dengan menjelaskan proses penyelesaian pada nomor 1 dan 2 . Karena 
pemahaman konsep sangat penting dalam mempelajari matematika, maka guru diharapkan mampu merancang kegiatan pembelajaran untuk meningkatkan pemahaman konsep siswa. Peneliti menyarankan untuk peneliti selanjutnya, disarankan untuk menggunakan lebih banyak indikator pemahaman konsep matematika dari ahli; melakukan penelitian untuk melihat kemampuan pemahaman konsep matematika untuk materi lainnya pada mata pelajaran yang berhubungan dengan matematika dan peneliti selanjutnya dapat mengembangkan/merancang pembelajaran yang dapat meningkatkan kemampuan pemahaman konsep matematika siswa karena pemahaman konsep sangat penting untuk dapat belajar matematika.

\section{DAFTAR PUSTAKA}

(2010).

Kemampuan Pemahaman

Matematis.

https://herdy07.wordpress.com/2010/05/27/kemampuan-pemahaman-matematis/.

Retrieved from wordpress.com.

Heriawan, A. (2012). Metologi Pembelajaran Kajian Teoritis Praktis. Banten: Perum Bumi Baros Chasanah.

Jihad, A. (2008). Pengembangan Kurikulum Matematika. Yogyakarta: Multi Pressindo.

Kilpatrick, Swafford.J, Findell. (2001). adding it Up: Helping Children Learn Mathematics. Washington DC: National Academy Press.

Moleong, L. J. (2013). Metodologi Penelitian Kualitatif. Bandung: PT. Remaja Rosda Karya.

Nanang. (2006). Model Pembelajaran. Makalah pada lokakarya Bagi Guru-Guru MTS.

Nelzon. (2002). Pembelajaran Matematika. Jakarta: Kencana.

Purba, A. (2020). Pemahaman Dalam Pembelajaran Matematika.

Rusman. (2010). Model-model Pembelajaran Mengembangkan Profesionalisme Guru. Jakarta: Rajawali Pers.

Sanjaya, W. (2009). Penelitian Tindakan Kelas. Jakarta: Kencana.

Skemp, R. (1976). Relational Understanding and Instrumental Understanding. Mathematics Teaching.

Sukjaya, S. d. (1990). Evaluasi Pendidikan Matematika. Bandung: Wijaya.

Wibawa, H. (2017). Analisis Pemahaman Konsep Matematika Siswa.

Zulkardi. (2003). Pendidikan Matematika Di Indonesia: Beberapa Permasalahan Dan Upaya Penyelesaiannya. Universitas Sriwijaya. 